\title{
Regioselective synthesis and biological evaluation of some novel thiophene- containing heterocyclic scaffolds as potential chemotherapeutic agents
}

\author{
Hatem Moustafa Gabera,* and Mark Christopher Bagleyb \\ a National Organization for Drug Control and Research (NODCAR), Cairo 12553, Egypt \\ b School of Chemistry, Cardiff University, Cardiff, CF10 3AT, U.K. \\ *Corresponding author at: National Organization for Drug Control and Research (NODCAR), Cairo 12553, Egypt. Tel.: +2.016.4703765; fax: +2.02.35728843. \\ E-mail address: hatem.gaber@yahoo.com (H.Gaber).
}

\section{ARTICLE INFORMATION}

Received: 24 February 2011

Received in revised form: 29 March 2011

Accepted: 29 March 2011

Online: 30 June 2011

\section{KEYWORDS}

Thienopyrimidinone

Cyclocondensation

Cyclodesulfurization

Hydrazinolysis

Alkylation

Antimicrobial activity

\begin{abstract}
In the reaction of 2-amino-3-carbethoxythiophene derivative $\mathbf{2 b}$ with hydrazine hydrate the respective aminocarbohydrazide $\mathbf{3}$ was isolated. Treatment of the latter product with carbon disulfide in alkaline medium caused a heterocyclization to give 1,3,4-oxadiazole-2-thione 5 rather than 3-amino-2-thioxothieno[2,3-d]pyrimidin-4-one $\mathbf{4}$, which could be obtained on treatment of carbohydrazide 3 with thiourea. The structure of products $\mathbf{4}$ and $\mathbf{5}$ was proved by spectroscopic methods and chemical transformations. Derivatization led to two novel series of condensed and uncondensed thiophenes, which were of significant interest for biological study. Since compound 4 contains two adjacent reactive functional groups, it reacted readily with different electrophilic reagents to provide a series of thieno[2,3d]pyrimidin-4-one derivatives with annelated bridgehead nitrogen heterocycles 8-11, whereas a second series of 3-heteroaryl-substituted thiophenes 13-17 was obtained by thioamide functionalization in 1,3,4-oxadiazole derivative $\mathbf{5}$ using various chemical reagents. The new thiophene-based derivatives were evaluated for their preliminary antimicrobial activity against a representative panel of Gram-positive and Gram-negative bacteria as well as fungi strains. The compounds tested displayed different levels of inhibitory effects, with the assays carried out on two pathogenic bacteria and two pathogenic fungi. Of these compounds, the monocyclic aminothiophene derivative 15 showed the highest effect on pathogenic bacteria, while the tricyclic condensed thiophene derivative $\mathbf{8}$ was observed to have the same inhibitory effect against pathogenic mould (Aspergillus flavus) as the reference drug Amphotericin B. For those derivatives belonging to first series of condensed thiophenes with annelated bridgehead nitrogen heterocycles, it has been observed that the antibacterial effect was in general found to be significantly higher than the corresponding uncondensed analogues. Although most of the condensed and uncondensed thiophenes under investigation showed generally remarkable in vitro antibacterial activity, unfortunately, no significant antifungal activity was observed with any of the compounds tested except for 8. Surprisingly, compound 8 displayed an excellent effect on fungus (A. flavus) on the one hand, whereas the lowest effect on bacteria on the other. The attachment of a triazolothiadiazine moiety to a thiophene ring could be considered as a promising strategy for the development of new therapeutic antibacterial agents related to the aminothiophene system.
\end{abstract}

\section{Introduction}

As a result of the dramatic increase in microbial infections, serious attention has been directed in recent years towards the discovery and development of new antimicrobial drugs. Fungal infections, mostly caused by Candida albicans, are often aggravated through the widespread use of broad-spectrum antibiotics, immunosuppressive agents, anticancer and antiAIDS drugs [1,2]. Despite advances in antimicrobial therapy, many problems remain to be solved for a new generation of antimicrobial agents. The main problem in the treatment of microbial infections is the increasing prevalence of drug resistance especially in patients chronically subjected to antimycotic therapy such as persons infected with HIV $[2,3]$. Therefore, the development of new and efficacious antimicrobial drugs is a very important goal, and most of the research efforts in this field are directed towards the design of new agents. A review of the recent literature shows that many effective antimicrobial agents contain a heterocyclic moiety within their structure $[4,5]$ with special emphasis on those agents incorporating a thiophene moiety [6-10]. The thiophene ring system is notably a structural component of the commercial imidazole antifungal agent sertaconazole [11]. In addition, the antimicrobial profile of condensed thiophenes, particularly their thieno[2,3- $d$ ] pyrimidin-4-one analogues, is also well categorized in the literature [12-14].

In searching for new compounds with a promising antimicrobial profile and as part of our ongoing studies in the development of new chemotherapeutic agents [15-17], we embarked upon the synthesis of a series of novel condensed tricyclic thiophene derivatives containing a thieno[2,3d] pyrimidin-4-one core fused through $\mathrm{N}-3$ and a second series of novel uncondensed derivatives bearing the same thiophene pharmacophore substituted with different heterocyclic 
fragments at C-3 in anticipation of the development of new broad spectrum antimicrobial agents which are devoid of the side effects associated with current therapeutic regimes.

\section{Experimental}

\subsection{Instrumentation}

Melting points are uncorrected. IR spectra were recorded $(\mathrm{KBr})$ on a Pye Unicam SP-1000 spectrophotometer. NMR spectra were obtained on a Varian Gemini $300 \mathrm{MHz}$ spectrometer in DMSO- $d_{6}$ as solvent and TMS as internal reference. Chemical shifts are expressed in $\delta \mathrm{ppm}$. Splitting patterns were designated as follows: s: singlet; d: doublet; $t$ : triplet; q: quartet; m: multiplet. EI mass spectra were recorded on a Shimadzu GC MS-QP 1000 EI mass spectrometer at $70 \mathrm{eV}$. Microanalytical data were found to be in satisfactory agreement with the theoretical values. The biological evaluation of the products was carried out at the Micro Analytical Center in Cairo University, Cairo, Egypt. Compounds 1 [18-22] and 2a [23] were prepared according to known methods (Scheme 1).

\subsection{Synthesis}

2.2.1. General procedure for the synthesis of ethyl 5-substituted-2-amino-4-phenylthiophene-3-carboxylates (2b-d)

Either aryl amine or heteroaryl amine $(0.0025 \mathrm{~mol})$ was dissolved in concentrated hydrochloric acid $(5 \mathrm{~mL})$ by warming, and the solution was stirred overnight at room temperature. The solution was then cooled to $0-5{ }^{\circ} \mathrm{C}$, a well cooled saturated solution of sodium nitrite $(0.0026 \mathrm{~mol})$ was added portionwise at $5-10{ }^{\circ} \mathrm{C}$, and the reaction content was stirred for a further $1 \mathrm{~h}$ at the same temperature. Excess nitrous acid was decomposed by the addition of urea, and the solution was cooled to $0-5{ }^{\circ} \mathrm{C}$. The resulting clear diazonium salt solution was then added dropwise over $20 \mathrm{~min}$ with constant stirring and with frequent addition of ice to a cold (0-5 $\left.{ }^{\circ} \mathrm{C}\right)$ stirred solution of coupling component aminoester $\mathbf{1}$ $(0.0023 \mathrm{~mol})$ dissolved in $20 \mathrm{~mL}$ of ethanol containing sodium acetate $(0.013 \mathrm{~mol})$ whilst maintaining a temperature at $0-5{ }^{\circ} \mathrm{C}$. After addition of the diazonium salt, the mixture was stirred for an additional $3 \mathrm{~h}$ at $5-10{ }^{\circ} \mathrm{C}$. The precipitated product, in each case, separated upon dilution with cold water $(30 \mathrm{~mL})$ was filtered off, washed with hot water and with cold water, and dried. Recrystallization from the appropriate solvents gave the azo derivatives $\mathbf{2 b}(0.62 \mathrm{~g} ; 71 \%)$, 2c (0.59 g; $59 \%)$ and $\mathbf{2 d}(0.47$ g; $42 \%$ ), respectively (Scheme 1).

\subsubsection{Ethyl 2-amino-5-(4-methoxyphenylazo)-4-phenyl thiophene-3-carboxylate (2b)}

This compound was obtained as a pale yellow solid (EtOH). M.p.: $141-142{ }^{\circ} \mathrm{C}$. IR $\left(\mathrm{v} / \mathrm{cm}^{-1}\right): 3470,3338\left(\mathrm{NH}_{2}\right), 3046$ (arom $\mathrm{CH}), 1672(\mathrm{CO}) .{ }^{1} \mathrm{H}$ NMR $(\delta \mathrm{ppm}): 0.96(\mathrm{t}, 3 \mathrm{H}, J=7.2 \mathrm{~Hz}$, ester $\mathrm{Me}), 3.85(\mathrm{~s}, 3 \mathrm{H}, \mathrm{OMe}), 4.16\left(\mathrm{q}, 2 \mathrm{H}, J=7.2 \mathrm{~Hz}\right.$, ester $\left.\mathrm{CH}_{2}\right), 5.91$ (s, br, $2 \mathrm{H}, \mathrm{NH}_{2}, \mathrm{D}_{2} \mathrm{O}$-exchangeable), 7.09-7.46 (m, 9H, $\mathrm{PhH}, \mathrm{ArH}$ ). Anal. Calcd. for $\mathrm{C}_{20} \mathrm{H}_{19} \mathrm{~N}_{3} \mathrm{O}_{3} \mathrm{~S}$ (381.448): $\mathrm{C}, 62.97 ; \mathrm{H}, 5.02 ; \mathrm{N}$, 11.02; S, 8.41. Found: C, 62.73; H, 4.91; N, 10.79; S, 8.32\%.

2.2.1.2. Ethyl 2-amino-5-[(3-cyano-4,5,6,7-tetrahydrobenzo [b]thiophen-2-yl)azo]-4-phenylthiophene-3-carboxylate (2c)

This compound was obtained as a brown solid (DMF/ $\left.\mathrm{H}_{2} \mathrm{O}\right)$. M.p.: $185-187{ }^{\circ} \mathrm{C}$. IR $\left(\mathrm{v} / \mathrm{cm}^{-1}\right)$ : 3457, $3332\left(\mathrm{NH}_{2}\right), 3050$ (arom CH), $2227(\mathrm{CN}), 1674(\mathrm{CO}) .{ }^{1} \mathrm{H}$ NMR $(\delta \mathrm{ppm}): 1.13(\mathrm{t}, 3 \mathrm{H}, J=7.2$ $\mathrm{Hz}$, ester Me), 1.71-1.85 (m, 4H, 2H-5, 2H-6), 2.44-2.56 (m, 4H,
$2 \mathrm{H}-4,2 \mathrm{H}-7$ ), 4.09 (q, 2H, $J=7.2 \mathrm{~Hz}$, ester $\mathrm{CH}_{2}$ ), 6.10 (s, br, $2 \mathrm{H}$, $\mathrm{NH}_{2}, \mathrm{D}_{2} \mathrm{O}$-exchangeable), 7.28-7.39 (m, 5H, PhH). Anal. Calcd. for $\mathrm{C}_{22} \mathrm{H}_{20} \mathrm{~N}_{4} \mathrm{O}_{2} \mathrm{~S}_{2}$ (436.550): C, 60.53; H, 4.62; N, 12.83; S, 14.69 . Found: C, 60.28; H, 4.50; N, 12.61; S, 14.52\%.

2.2.1.3. Ethyl 2-[(5-amino-4-(ethoxycarbonyl)-3-phenyl thiophen-2-yl)azo]-4,5,6,7-tetrahydrobenzo[b] thiophene-3carboxylate (2d)

This compound was obtained as a reddish brown solid (1,4dioxane). M.p.: $162{ }^{\circ} \mathrm{C}$. IR $\left(\mathrm{v} / \mathrm{cm}^{-1}\right): 3463,3345\left(\mathrm{NH}_{2}\right), 3041$ (arom CH), 1712, $1674(2 \mathrm{CO}) .{ }^{1} \mathrm{H}$ NMR $(\delta \mathrm{ppm}): 1.07(\mathrm{t}, 3 \mathrm{H}, J=$ $7.2 \mathrm{~Hz}$, ester Me), $1.41(\mathrm{t}, 3 \mathrm{H}, J=7.5 \mathrm{~Hz}$, ester Me), 1.66-1.79 (m, $4 \mathrm{H}, 2 \mathrm{H}-5,2 \mathrm{H}-6), 2.45-2.50$ (m, 2H, 2H-4), 2.67-2.72 (m, $2 \mathrm{H}, 2 \mathrm{H}-$ 7), $4.13\left(\mathrm{q}, 2 \mathrm{H}, J=7.2 \mathrm{~Hz}\right.$, ester $\left.\mathrm{CH}_{2}\right), 4.28(\mathrm{q}, 2 \mathrm{H}, J=7.5 \mathrm{~Hz}$ ester $\mathrm{CH}_{2}$ ), 5.82 (s, br, $2 \mathrm{H}, \mathrm{NH}_{2}, \mathrm{D}_{2} \mathrm{O}$-exchangeable), 7.26-7.39 (m, 5H, PhH). Anal. Calcd. for $\mathrm{C}_{24} \mathrm{H}_{25} \mathrm{~N}_{3} \mathrm{O}_{4} \mathrm{~S}_{2}$ (483.603): C, 59.61; H, 5.21; N, 8.69; S, 13.26. Found: C, 59.41; H, 5.06; N, 8.51; S, $13.03 \%$.

\subsubsection{Synthesis of 2-amino-5-(4-methoxyphenylazo)-4- phenylthiophene-3-carbohydrazide (3)}

Hydrazine hydrate $(0.015 \mathrm{~mol})$ was added to a solution of compound $2 \mathbf{b}(0.003 \mathrm{~mol})$ in absolute ethanol $(20 \mathrm{~mL})$. The reaction mixture was refluxed for $4 \mathrm{~h}$, concentrated in vacuo, cooled and diluted with water. The obtained precipitate was collected by filtration, washed with cold water, dried and purified by recrystallization from methanol to give yellow crystals of the title compound $3(0.71 \mathrm{~g} ; 64 \%)$ (Scheme 1). M.p.: 193-194 ${ }^{\circ} \mathrm{C}$. IR $\left(\mathrm{v} / \mathrm{cm}^{-1}\right)$ : 3382-3175 $\left(\mathrm{NH}, \mathrm{NH}_{2}\right), 3056$ (arom $\mathrm{CH}), 1660$ (hydrazide CO). ${ }^{1} \mathrm{H}$ NMR $(\delta \mathrm{ppm}): 3.90$ (s, 3H, OMe), 4.57 (s, $2 \mathrm{H}$, hydrazide $\mathrm{NH}_{2}, \mathrm{D}_{2} \mathrm{O}$-exchangeable), $6.85\left(\mathrm{~s}, 2 \mathrm{H}, \mathrm{NH}_{2}\right.$, $\mathrm{D}_{2} \mathrm{O}$-exchangeable), 7.14-7.49 (m, 9H, PhH, ArH), $9.36(\mathrm{~s}, 1 \mathrm{H}$, $\mathrm{NH}, \mathrm{D}_{2} \mathrm{O}$-exchangeable). MS ( $\left.\mathrm{m} / \mathrm{z}(\%)\right): 367\left(\mathrm{M}^{+}, 17 \%\right)$. Anal. Calcd. for $\mathrm{C}_{18} \mathrm{H}_{17} \mathrm{~N}_{5} \mathrm{O}_{2} \mathrm{~S}$ (367.425): C, 58.84; $\mathrm{H}, 4.66 ; \mathrm{N}, 19.06$; , 8.73. Found: C, 58.62; H, 4.50; N, 18.86; S, 8.61\%.

\subsubsection{Synthesis of 3-amino-6-(4-methoxyphenylazo)-5- phenyl-2-thioxo-2,3-dihydrothieno[2,3-d]pyrimidin-4(1H)- one (4)}

A mixture of aminocarbohydrazide $3(0.002 \mathrm{~mol})$ and thiourea $(1.0 \mathrm{~g})$ was dissolved in dimethylformamide $(30 \mathrm{~mL})$ and refluxed for $4 \mathrm{~h}$. After cooling to room temperature, the reaction mixture was poured over iced water. The resulting precipitate of solid product was collected by filtration and recrystallized from aqueous dimethylformamide to give the corresponding thienopyrimidinone derivative $\mathbf{4}$ as a light brown solid (0.63 g; 77\%) (Scheme 1). M.p.: 219-221 ${ }^{\circ} \mathrm{C}$. IR $\left(\mathrm{v} / \mathrm{cm}^{-1}\right)$ : 3310-3204 (NH, NH$\left.)_{2}\right), 3059$ (arom CH), 1687 (CO), 1425 (CS). ${ }^{1} \mathrm{H}$ NMR $(\delta \mathrm{ppm}): 3.87(\mathrm{~s}, 3 \mathrm{H}, \mathrm{OMe}), 6.20\left(\mathrm{~s}, 2 \mathrm{H}, \mathrm{NH}_{2}\right.$, $\mathrm{D}_{2} \mathrm{O}$-exchangeable), 7.20-7.51 (m, 9H, PhH, ArH), 12.58 (s, br, $1 \mathrm{H}, \mathrm{NH}, \mathrm{D}_{2} \mathrm{O}$-exchangeable). ${ }^{13} \mathrm{C}$ NMR $(\delta \mathrm{ppm}): 54.7$ (OMe), $115.1,118.7,125.1,127.3,128.9,129.5,132.5,134.6,140.7$, 152.8, 153.2, 158.3 (CO), 159.2 (C-OMe), 172.6 (CS). Anal. Calcd. for $\mathrm{C}_{19} \mathrm{H}_{15} \mathrm{~N}_{5} \mathrm{O}_{2} \mathrm{~S}_{2}$ (409.485): C, 55.73; H, 3.69; N, 17.10; $\mathrm{S}, 15.66$. Found: C, 55.56; H, 3.50; N, 16.89; S, 15.52\%.

\subsubsection{Synthesis of 5-[2-amino-5-(4-methoxyphenylazo)-4- phenylthiophen-3-yl]-1,3,4-oxadiazole-2(3H)-thione (5)}

Potassium hydroxide $(0.005 \mathrm{~mol})$ was dissolved in ethanol $(5 \mathrm{~mL})$ and carbon disulfide $(0.017 \mathrm{~mol})$ was added to the solution, and the reaction content was stirred at room temperature for $15 \mathrm{~min}$. Then, hydrazide $3(0.005 \mathrm{~mol})$ in ethanol ( $5 \mathrm{~mL})$ was added and the reaction mixture was heated under reflux with stirring until the evolution of hydrogen 


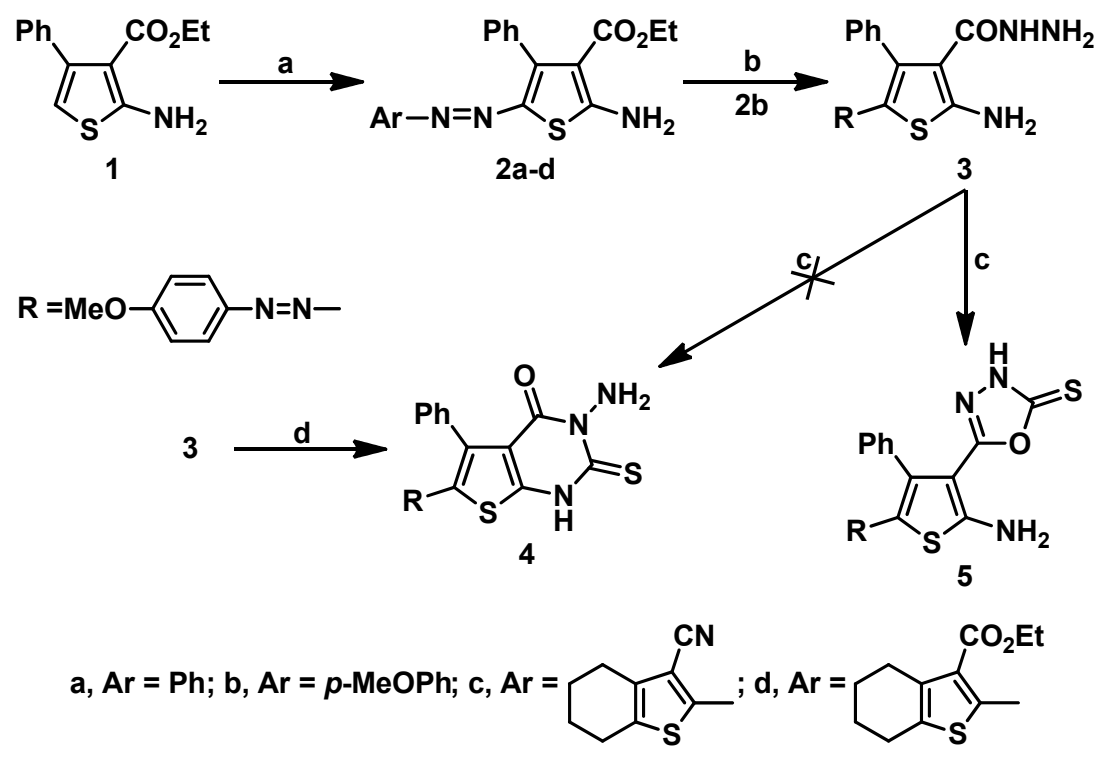

\section{Reagents and conditions: (a) $\mathrm{ArN}_{2} \mathrm{Cl} / \mathrm{EtOH} / \mathrm{AcONa} / 0-5^{\circ} \mathrm{C}$; (b) $\mathrm{N}_{2} \mathrm{H}_{4} \cdot \mathrm{H}_{2} \mathrm{O} / \mathrm{EtOH} / \Delta$; (c) $\mathrm{CS}_{2} / \mathrm{KOH} / \mathrm{EtOH} / \Delta$ then $\mathrm{HCl}$; (d) $\mathrm{CS}\left(\mathrm{NH}_{2}\right)_{2} / \mathrm{DMF} / \Delta$}

Scheme 1

sulfide stopped $(\sim 12 \mathrm{~h})$. Most of the solvent was removed under reduced pressure and the residue was dissolved in water $(2 \mathrm{~mL})$ and carefully acidified with concentrated hydrochloric acid $(0.5 \mathrm{~mL})$. The resulting precipitate was collected by filtration, washed with cold water and air-dried. Recrystallization from ethanol gave the 1,3,4-oxadiazole-2thione derivative 5 as a yellow solid $(0.82 \mathrm{~g} ; 40 \%)$ (Scheme 1). M.p.: $171-172{ }^{\circ} \mathrm{C}$. IR $\left(\mathrm{v} / \mathrm{cm}^{-1}\right): 3300-3136\left(\mathrm{NH}, \mathrm{NH}_{2}\right), 3060$ (arom CH), 1471 (CS), 1070 (C-0-C). ${ }^{1} \mathrm{H}$ NMR $(\delta$ ppm): 3.88 (s, $3 \mathrm{H}, \mathrm{OMe}), 6.34\left(\mathrm{~s}, 2 \mathrm{H}, \mathrm{NH}_{2}, \mathrm{D}_{2} \mathrm{O}\right.$-exchangeable), 7.12-7.45 (m, 9H, $\mathrm{PhH}, \mathrm{ArH}$ ), 13.65 (s, br, $1 \mathrm{H}, \mathrm{NH}, \mathrm{D}_{2} \mathrm{O}$-exchangeable). ${ }^{13} \mathrm{C}$ NMR ( $\delta \mathrm{ppm}): 55.0$ (OMe), 111.3, 114.8, 125.2, 127.4, 128.7, 129.4, 131.7, 134.9, 140.5, 153.0, 159.1 (C-OMe), 160.8, 161.3 (thiophene C-2, oxadiazole C-5), 177.5 (CS). Anal. Calcd. for $\mathrm{C}_{19} \mathrm{H}_{15} \mathrm{~N}_{5} \mathrm{O}_{2} \mathrm{~S}_{2}$ (409.485): C, 55.73; H, 3.69; N, 17.10; S, 15.66. Found: C, 55.49; H, 3.46; N, 16.94; S, 15.49\%.

\subsubsection{Synthesis of 6-(4-methoxyphenylazo)-3,7-diphenyl-2- thioxo-2,3-dihydrothieno[2,3-d][1,2,4]triazolo[1,5-a] pyrimidin-8(1H)-one (8)}

To a solution of compound $4(0.002 \mathrm{~mol})$ in ethanolic sodium ethoxide [prepared by dissolving sodium metal $(0.002$ $\mathrm{mol})$ in absolute ethanol $(25 \mathrm{~mL})]$, phenyl isothiocyanate $(0.002 \mathrm{~mol})$ was added dropwise. The mixture was refluxed with stirring for $10 \mathrm{~h}$ and then left to cool to room temperature overnight under stirring. The reaction mixture was then poured onto iced water and neutralized with dilute hydrochloric acid, whereby the resulting solid product was filtered off, dried and recrystallized from dimethylformamide to give the triazole-2thione derivative 8 as a dark brown solid (0.57 g; 56\%) (Scheme 2). M.p.: 270-271 ${ }^{\circ} \mathrm{C}$. IR (v/ $\left.\mathrm{cm}^{-1}\right): 3207$ (NH), 3066 (arom CH), 1685 (CO), $1397(\mathrm{CS}) \mathrm{cm}^{-1} .{ }^{1} \mathrm{H}$ NMR $(\delta \mathrm{ppm}): 3.87$ (s, $3 \mathrm{H}, \mathrm{OMe}), 6.91-7.56(\mathrm{~m}, 14 \mathrm{H}, 2 \mathrm{PhH}, \mathrm{ArH}), 13.97$ (s, 1H, NH, $\mathrm{D}_{2} \mathrm{O}$-exchangeable). ${ }^{13} \mathrm{C}$ NMR $(\delta \mathrm{ppm}): 54.7$ (OMe), 114.6, 119.0, $125.4,127.2$, 127.6, 128.5, 128.8, 129.1, 129.6, 132.5, 133.1, 134.7, 140.8, 152.6, 153.3, 157.0, 158.7 (CO), 159.5 (C-OMe), 173.2 (CS). Anal. Calcd. for $\mathrm{C}_{26} \mathrm{H}_{18} \mathrm{~N}_{6} \mathrm{O}_{2} \mathrm{~S}_{2}$ (510.590): C, 61.16; $\mathrm{H}$, 3.55; N, 16.46; S, 12.56. Found: C, 60.96; H, 3.41; N, 16.29; S, $12.41 \%$.
2.2.6. Synthesis of 7-(4-methoxyphenylazo)-2,8-diphenyl-3Hthieno[2',3':4,5]pyrimidino[2,1-b][1,3,4]thiadiazin-9-one (9)

A solution of phenacyl bromide $(0.004 \mathrm{~mol})$ in ethanol (2 $\mathrm{mL}$ ) was added to a solution of compound $4(0.004 \mathrm{~mol})$ and potassium hydroxide $(0.004 \mathrm{~mol})$ in ethanol $(8 \mathrm{~mL})$, and the reaction content was heated for 30 min under reflux. The reaction mixture was cooled and diluted with water $(20 \mathrm{~mL})$, whereby the precipitate of solid product was collected by filtration and dried. The residue was purified by recrystallization from ethanol to obtain the tricyclic thiadiazine derivative 9 as a canary yellow solid (0.65 g; 32\%) (Scheme 2). M.p.: $253-256{ }^{\circ} \mathrm{C}$. IR (v/cm-1): 3071 (arom CH), 1710 (CO). ${ }^{1} \mathrm{H}$ NMR ( $\delta \mathrm{ppm}): 3.90(\mathrm{~s}, 3 \mathrm{H}, \mathrm{OMe}), 4.43\left(\mathrm{~s}, 2 \mathrm{H}, \mathrm{SCH}_{2}\right), 7.12-7.74$ (m, $14 \mathrm{H}, 2 \mathrm{PhH}, \mathrm{ArH}$ ). Anal. Calcd. for $\mathrm{C}_{27} \mathrm{H}_{19} \mathrm{~N}_{5} \mathrm{O}_{2} \mathrm{~S}_{2}$ (509.602): C, 63.64; H, 3.76; N, 13.74; S, 12.58. Found: C, 63.39; H, 3.61; N, $13.56 ; \mathrm{S}, 12.37 \%$.

2.2.7. Synthesis of 7-(4-methoxyphenylazo)-8-phenyl-1H,3Hthieno[2',3':4,5]pyrimidino[2,1-b][1,3,4]thiadiazin-2,9-dione (10)

\subsubsection{Method A}

A mixture of compound $4(0.002 \mathrm{~mol})$, chloroacetic acid $(0.002 \mathrm{~mol})$ and anhydrous sodium acetate $(0.002 \mathrm{~mol})$ in absolute ethanol (15 mL) was refluxed on a steam bath for $6 \mathrm{~h}$, then cooled and poured onto cold water. The separated solid product was collected by filtration, washed repeatedly with water, dried and recrystallized from a mixture of 1,4-dioxane and water to give the respective thiadiazinone derivative $\mathbf{1 0}$ as a brown solid (0.49 g; 55\%) (Scheme 2). M.p.: > $300{ }^{\circ} \mathrm{C}$. IR (v/ $\left.\mathrm{cm}^{-1}\right): 3167(\mathrm{NH}), 3071$ (arom CH), 1705, $1684(2 \mathrm{CO}) .{ }^{1} \mathrm{H}$ NMR ( $\delta$ ppm): $3.85(\mathrm{~s}, 3 \mathrm{H}, \mathrm{OMe}), 3.94\left(\mathrm{~s}, 2 \mathrm{H}, \mathrm{SCH}_{2}\right), 7.15-7.46$ (m, 9H, PhH, ArH), 11.59 (s, 1H, NH, $\mathrm{D}_{2} \mathrm{O}$-exchangeable). MS ( $m / z$ (\%)): $449\left(\mathrm{M}^{+}, 29 \%\right)$. Anal. Calcd. for $\mathrm{C}_{21} \mathrm{H}_{15} \mathrm{~N}_{5} \mathrm{O}_{3} \mathrm{~S}_{2}$ (449.505): C, 56.11; H, 3.36; N, 15.58; S, 14.27. Found: C, 55.88; H, 3.21; N, 15.36; S, 14.08\%. 


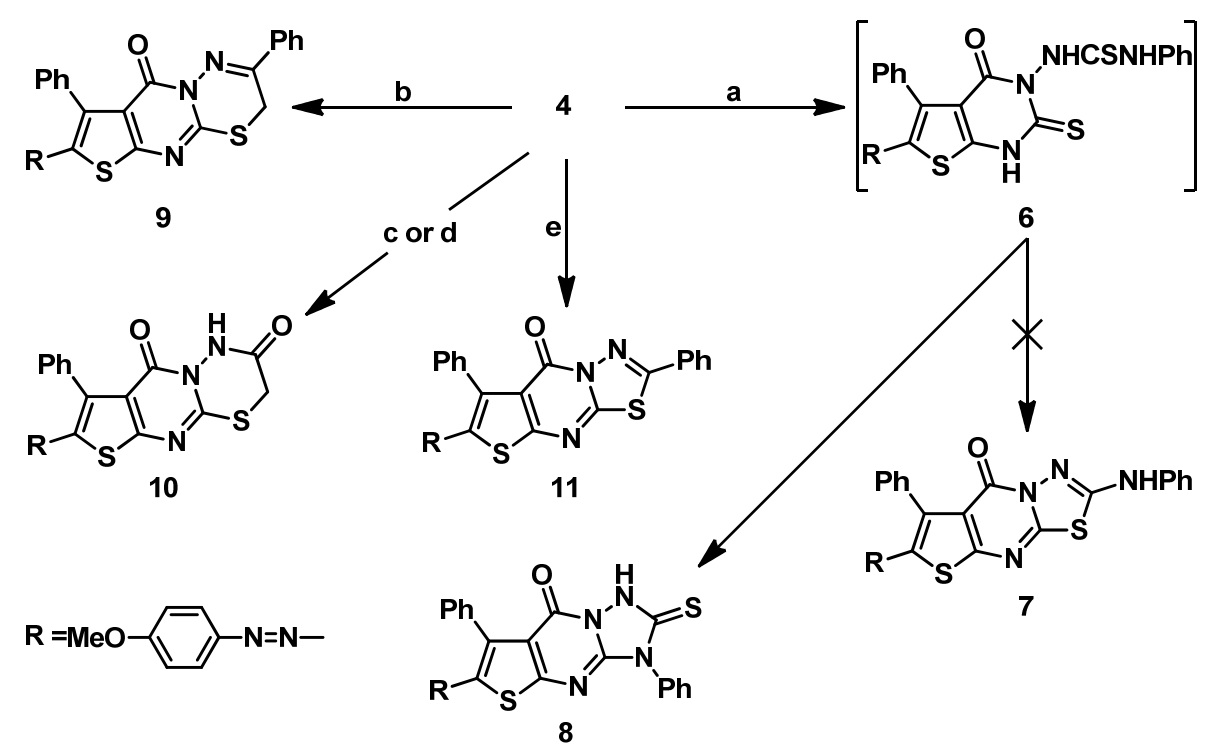

Reagents and conditions: (a) PhNCS/NaOEt/EtOH $/ \Delta$; (b) $\mathrm{PhCOCH} \mathrm{Br}_{2} / \mathrm{KOH} / \mathrm{EtOH} / \Delta$; (c)
$\mathrm{ClCH}_{2} \mathrm{CO}_{2} \mathrm{H} / \mathrm{AcONa} / \mathrm{EtOH} / \Delta$; (d) $\mathrm{ClCH}_{2} \mathrm{CO}_{2} \mathrm{Et} / \mathrm{NaOEt} / \mathrm{EtOH} / \Delta$; (e) $\mathrm{PhCO}_{2} \mathrm{H} / \mathrm{POCl}_{3} / \Delta$

Scheme 2

\subsubsection{Method B}

A mixture of compound $4(0.002 \mathrm{~mol})$ and ethyl chloroacetate $(0.002 \mathrm{~mol})$, was added with stirring to sodium ethoxide [obtained from $0.046 \mathrm{~g}(0.002 \mathrm{~mol})$ of metallic sodium and $15 \mathrm{~mL}$ of absolute ethanol]. The reaction content was refluxed with stirring for $3 \mathrm{~h}$. The solvent was distilled off and water was added. The precipitate was filtered off, dried and recrystallized from 1,4-dioxane/water to give a solid product, in $43 \%$ yield, identical in all aspects (mp, mixed mp and IR data) to that obtained above from method $\mathrm{A}$.

\subsubsection{Synthesis of 6-(4-methoxyphenylazo)-2,7-diphenyl-8H- [1,3,4]thiadiazolo[3,2-a]thieno[2,3-d]pyrimidin-8-one (11)}

A mixture of compound $4(0.002 \mathrm{~mol})$ and benzoic acid $(0.004 \mathrm{~mol})$ in phosphorus oxychloride $(10 \mathrm{~mL})$ was refluxed for $1 \mathrm{~h}$. The reaction mixture was concentrated to third its volume under reduced pressure and left to cool. The mixture was then poured gradually onto a stirred ice cold sodium hydroxide solution to remove unreacted materials. The obtained precipitate was collected by filtration, washed thoroughly with water, dried and purified by recrystallization from acetic acid to give light brown crystals of the title compound 11 (0.59 g; 60\%) (Scheme 2). M.p.: $263^{\circ} \mathrm{C}$. IR (v/cm 1): 3065 (arom CH), 1714 (CO). ${ }^{1} \mathrm{H}$ NMR $(\delta$ ppm): $3.86(\mathrm{~s}, 3 \mathrm{H}$, OMe), 7.18-7.64 (m, 14H, $2 \mathrm{PhH}, \mathrm{ArH})$. MS (m/z (\%)): $495\left(\mathrm{M}^{+}\right.$, 21\%). Anal. Calcd. for $\mathrm{C}_{26} \mathrm{H}_{17} \mathrm{~N}_{5} \mathrm{O}_{2} \mathrm{~S}_{2}$ (495.575): $\mathrm{C}, 63.01 ; \mathrm{H}, 3.46$; N, 14.13; S, 12.94. Found: C, 62.83; H, 3.25; N, 13.96; S, 12.70\%.

\subsubsection{Synthesis of 4-amino-3-[2-amino-5-(4-methoxy phenylazo)-4-phenylthiophen-3-yl]-1H-1,2,4-triazole-5(4H)- thione (13)}

To a suspension of compound $5(0.003 \mathrm{~mol})$ in ethanol (10 $\mathrm{mL})$, hydrazine hydrate $(0.0095 \mathrm{~mol})$ was added dropwise. The reaction content was heated at reflux for $7 \mathrm{~h}$, then left to cool and poured onto crushed ice. The reaction mixture was acidified with dilute hydrochloric acid. The formed precipitate was collected by filtration, washed with water and dried. Recrystallization from aqueous dimethylformamide gave the $\mathrm{N}$ amino compound 13 as a yellowish white solid (0.99 g; 78\%) (Scheme 3). M.p.: 233-236 ${ }^{\circ} \mathrm{C}$. IR $\left(\mathrm{v} / \mathrm{cm}^{-1}\right): 3340-3112(\mathrm{NH}$, $\mathrm{NH}_{2}$ ), 3061 (arom CH), $1462(\mathrm{CS}) .{ }^{1} \mathrm{H}$ NMR $(\delta \mathrm{ppm}): 3.88(\mathrm{~s}, 3 \mathrm{H}$, $\mathrm{OMe}$ ), 5.72 (s, $2 \mathrm{H}, \mathrm{N}-\mathrm{NH}_{2}, \mathrm{D}_{2} \mathrm{O}$-exchangeable), 6.50 (s, $2 \mathrm{H}, \mathrm{NH}_{2}$, $\mathrm{D}_{2} \mathrm{O}$-exchangeable), 7.21-7.55 (m, 9H, PhH, ArH), 13.24 (s, br, $1 \mathrm{H}, \mathrm{NH}, \mathrm{D}_{2} \mathrm{O}$-exchangeable). MS $(\mathrm{m} / \mathrm{z}(\%)): 423\left(\mathrm{M}^{+}, 14 \%\right)$. Anal. Calcd. for $\mathrm{C}_{19} \mathrm{H}_{17} \mathrm{~N}_{7} \mathrm{OS}_{2}$ (423.515): $\mathrm{C}, 53.88 ; \mathrm{H}, 4.05 ; \mathrm{N}$, 23.15; S, 15.14. Found: C, 53.69; H, 3.89; N, 22.92; S, 14.97\%.

2.2.10. Synthesis of 5-substituted-2-[2-amino-5-(4-methoxy phenylazo)-4-phenylthiophen-3-yl]-1,3,4-oxadiazoles $(14 a, b)$

A solution of methyl iodide or phenacyl bromide $(0.005$ $\mathrm{mol})$ in ethanol $(2.5 \mathrm{~mL})$ was added to a solution of compound $5(0.005 \mathrm{~mol})$ and potassium hydroxide in ethanol $(10 \mathrm{~mL})$. The reaction content was heated for $30 \mathrm{~min}$ under reflux. And then ice/water mixture was added to the reaction mixture to form precipitates, which were collected by filtration, dried and recrystallized from the proper solvents to obtain the title compounds 14a (0.85 g; 40\%) and 14b (0.87 g; 33\%), respectively (Scheme 3).

\subsubsection{2-[2-amino-5-(4-methoxyphenylazo)-4-phenyl thiophen-3-yl]-5-methylthio-1,3,4-oxadiazole (14a)}

This compound was obtained as a brown solid $(\mathrm{MeOH})$ (Scheme 3). M.p.: $120-121^{\circ} \mathrm{C}$. IR $\left(\mathrm{v} / \mathrm{cm}^{-1}\right): 3450,3341\left(\mathrm{NH}_{2}\right)$, 3060 (arom CH), 1064 (C-O-C). ${ }^{1} \mathrm{H}$ NMR $(\delta \mathrm{ppm}): 2.73(\mathrm{~s}, 3 \mathrm{H}$, $\mathrm{SMe}$ ), 3.85 (s, 3H, OMe), 6.29 (s, 2H, NH $\mathrm{N}_{2}, \mathrm{D}_{2} \mathrm{O}$-exchangeable), 7.08-7.40 (m, 9H, PhH, ArH). Anal. Calcd. for $\mathrm{C}_{20} \mathrm{H}_{17} \mathrm{~N}_{5} \mathrm{O}_{2} \mathrm{~S}_{2}$ (423.511): C, 56.72; H, 4.05; N, 16.54; S, 15.14. Found: C, 56.48; H, 3.91; N, 16.37; S, 14.94\%. 


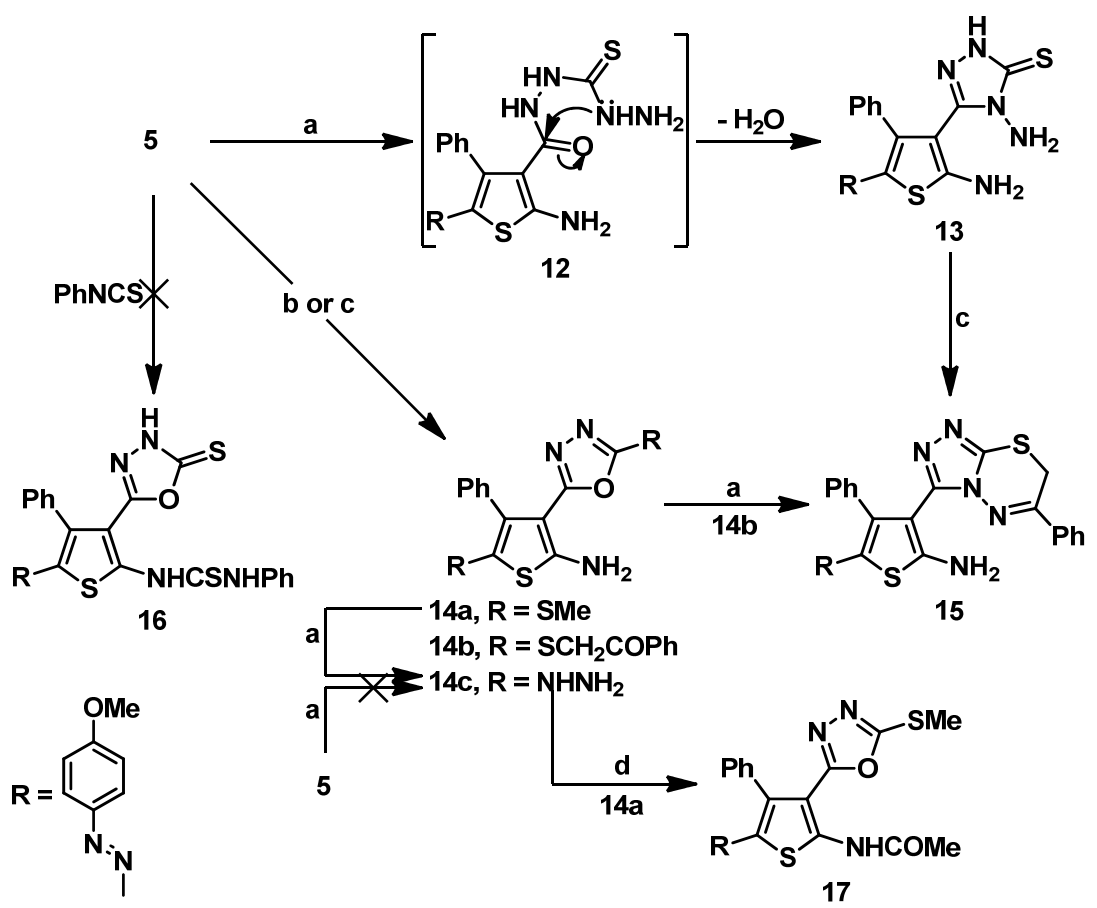

Reagents and conditions: (a) $\mathrm{N}_{2} \mathrm{H}_{4} \cdot \mathrm{H}_{2} \mathrm{O} / \mathrm{EtOH} / \Delta$; (b) Mel/KOH/EtOH$/ \Delta$; (c) $\mathrm{PhCOCH}{ }_{2} \mathrm{Br} / \mathrm{KOH} / \mathrm{EtOH} / \Delta$; (d) $\mathrm{Ac}_{2} \mathrm{O} / \mathrm{C}_{5} \mathrm{H}_{5} \mathrm{~N} /$ room temperature.

Scheme 3

\subsubsection{2-[2-amino-5-(4-methoxyphenylazo)-4-phenyl thiophen-3-yl]-5-phenacylthio-1,3,4-oxadiazole (14b)}

This compound was obtained as a pale yellow solid (EtOH) (Scheme 3). M.p.: 213-215 ${ }^{\circ} \mathrm{C}$. IR $\left(\mathrm{v} / \mathrm{cm}^{-1}\right): 3441,3335\left(\mathrm{NH}_{2}\right)$, 3064 (arom CH), 1692 (CO), 1062 (C-0-C). ${ }^{1} \mathrm{H}$ NMR ( $\left.\delta \mathrm{ppm}\right)$ : 3.85 (s, 3H, OMe), 4.91 (s, 2H, SCH 2$), 6.44\left(\mathrm{~s}, 2 \mathrm{H}, \mathrm{NH}_{2}, \mathrm{D}_{2} \mathrm{O}-\right.$ exchangeable), 7.26-7.84 (m, 14H, 2PhH, ArH). Anal. Calcd. for $\mathrm{C}_{27} \mathrm{H}_{21} \mathrm{~N}_{5} \mathrm{O}_{3} \mathrm{~S}_{2}$ (527.617): C, 61.46; H, 4.01; N, 13.27; S, 12.15. Found: C, 61.24; H, 3.90; N, 13.04; S, 11.96\%.

\subsubsection{Synthesis of 2-[2-amino-5-(4-methoxyphenylazo)-4- phenylthiophen-3-yl]-5-hydrazino-1,3,4-oxadiazole (14c)}

Compound 14a (0.002 mol) was mixed with hydrazine hydrate $(1 \mathrm{~mL}, 0.02 \mathrm{~mol})$ in absolute ethanol $(8 \mathrm{~mL})$. The reaction content was heated at reflux for $5 \mathrm{~h}$ and then held overnight at room temperature. After cooling and dilution with water, the obtained precipitate was filtered off, dried and purified by recrystallization from an ethanol and dimethylformamide mixture $(2: 1)$ to give reddish brown crystals of the title compound 14c (0.40 g; 49\%) (Scheme 3 ). M.p.: $227-228{ }^{\circ} \mathrm{C}$. IR $\left(\mathrm{v} / \mathrm{cm}^{-1}\right)$ : 3410-3202 (NH, NH $\left.\mathrm{NH}_{2}\right), 3053$ (arom CH), 1071 (C-O-C). ${ }^{1} \mathrm{H}$ NMR $(\delta \mathrm{ppm}): 3.87$ (s, 3H, OMe), 4.83 (s, br, 2H, $\mathrm{NH}_{2}, \mathrm{D}_{2} \mathrm{O}$-exchangeable), 6.57 (s, 2H, $\mathrm{NH}_{2}, \mathrm{D}_{2} \mathrm{O}$ exchangeable), 7.10-7.44 (m, 9H, $\mathrm{PhH}, \mathrm{ArH}), 10.35(\mathrm{~s}, \mathrm{br}, 1 \mathrm{H}$, $\mathrm{NH}, \mathrm{D}_{2} \mathrm{O}$-exchangeable). $\mathrm{MS}(\mathrm{m} / \mathrm{z}(\%)): 407\left(\mathrm{M}^{+}, 25 \%\right)$. Anal. Calcd. for $\mathrm{C}_{19} \mathrm{H}_{17} \mathrm{~N}_{7} \mathrm{O}_{2} \mathrm{~S}$ (407.449): C, 56.01; H, 4.21; N, 24.06; S, 7.87. Found: C, 55.76; H, 4.01; N, 23.87; S, 7.75\%.

2.2.14. Synthesis of 3-[2-amino-5-(4-methoxyphenylazo)-4phenylthiophen-3-yl]-6-phenyl-7H-1,2,4-triazolo[3,4-b]1,3,4-thiadiazine (15)

2.2.14.1. Method A
A solution of phenacyl bromide $(0.004 \mathrm{~mol})$ in ethanol $(2$ $\mathrm{mL}$ ) was added to a solution of 4-aminotriazole-2-thione derivative $13(0.004 \mathrm{~mol})$ and potassium hydroxide $(0.004$ $\mathrm{mol})$ in ethanol $(8 \mathrm{~mL})$. The reaction mixture was processed as described before for the synthesis of $\mathbf{9}$. It was purified by recrystallization from a mixture of ethanol and dimethylformamide to obtain compound $\mathbf{1 5}$ as a dark brown solid $(0.73 \mathrm{~g}$; $35 \%)$ (Scheme 3). M.p.: > $300{ }^{\circ} \mathrm{C}$. IR $\left(v / \mathrm{cm}^{-1}\right)$ : 3437, $3346\left(\mathrm{NH}_{2}\right), 3060(\mathrm{CH}$ arom $) .{ }^{1} \mathrm{H}$ NMR $(\delta \mathrm{ppm}): 3.91(\mathrm{~s}$, $3 \mathrm{H}, \mathrm{OMe}), 4.52\left(\mathrm{~s}, 2 \mathrm{H}, \mathrm{SCH}_{2}\right), 6.63\left(\mathrm{~s}, 2 \mathrm{H}, \mathrm{NH}_{2}, \mathrm{D}_{2} \mathrm{O}-\right.$ exchangeable), 7.25-7.78 (m, 14H, $2 \mathrm{PhH}, \mathrm{ArH})$. Anal. Calcd. for $\mathrm{C}_{27} \mathrm{H}_{21} \mathrm{~N}_{7} \mathrm{OS}_{2}$ (523.632): C, 61.93; $\mathrm{H}, 4.04 ; \mathrm{N}, 18.72 ; \mathrm{S}, 12.25$. Found: $\mathrm{C}, 61.76 ; \mathrm{H}, 3.94 ; \mathrm{N}, 18.48 ; \mathrm{S}, 12.03 \%$.

\subsubsection{Method B}

The same product was synthesized from compound $\mathbf{1 4 b}$ $(0.002 \mathrm{~mol})$ and hydrazine hydrate $(0.005 \mathrm{~mol})$ in a manner similar to that described before for the synthesis of compound 13 (reaction time: $12 \mathrm{~h}$ ). It was recrystallized from an ethanol and dimethylformamide mixture to give a solid product, in $42 \%$ yield, identical in all respects ( $\mathrm{mp}$, mixed $\mathrm{mp}$ and IR data) to the $\mathrm{N}$-amino compound 15 (Scheme 3 ).

2.2.15. Synthesis of 2-[2-N-acetylamino-5-(4-methoxy phenylazo)-4-phenylthiophen-3-yl]-5-methylthio-1,3,4oxadiazole (17)

A stirred solution of compound $\mathbf{1 4 a}(0.003 \mathrm{~mol})$ in dry pyridine $(10 \mathrm{~mL})$, was treated with acetic anhydride $(8 \mathrm{~mL})$. The reaction content was kept for $48 \mathrm{~h}$ at room temperature with occasional stirring and then poured onto cruched ice. The material which separated out was isolated by filtration, washed with water and dried. The residue was recrystallized from ethanol to give the corresponding 2-acetylamino derivative 17 
as a canary yellow solid (0.50 g; 36\%) (Scheme 3). M.p.: 154$155{ }^{\circ} \mathrm{C}$. IR (v/ $\left.\mathrm{cm}^{-1}\right): 3270(\mathrm{NH}), 3065$ (arom CH), 1681 (CO), 1064 (C-O-C). ${ }^{1} \mathrm{H}$ NMR $(\delta \mathrm{ppm}): 2.18(\mathrm{~s}, 3 \mathrm{H}, \mathrm{COMe}), 2.76(\mathrm{~s}, 3 \mathrm{H}$, $\mathrm{SMe}$ ), 3.85 (s, 3H, OMe), 7.13-7.42 (m, 9H, PhH, ArH), 10.54 (s, $1 \mathrm{H}, \mathrm{NH}, \mathrm{D}_{2} \mathrm{O}$-exchangeable). MS $(\mathrm{m} / z(\%)): 465\left(\mathrm{M}^{+}, 19 \%\right)$. Anal. Calcd. for $\mathrm{C}_{22} \mathrm{H}_{19} \mathrm{~N}_{5} \mathrm{O}_{3} \mathrm{~S}_{2}$ (465.548): C, 56.76; $\mathrm{H}, 4.11$; N, 15.04; S, 13.78. Found: C, 56.54; H, 3.99; N, 14.83; S, 13.60\%.

\subsection{Microbiology}

\subsubsection{Antimicrobial activity}

The preliminary antimicrobial activity was investigated on four newly-obtained condensed thiophenes containing different $\mathrm{N}$-heterocyclic moieties as well as six new uncondensed thiophenes having various heterocycles at position 3 in order to increase the selectivity of these derivatives towards test microorganisms. Screening results are summarized in Table 1.

Table 1. In vitro antimicrobial activity of test compounds

\begin{tabular}{lcccc}
\hline \multirow{2}{*}{ Compd. } & \multicolumn{4}{c}{ IZD $^{\mathbf{b}}(\mathbf{m m})$} \\
\cline { 2 - 5 } & \multicolumn{3}{c}{ Bacteria } & \multicolumn{3}{c}{ Fungi } \\
\cline { 2 - 5 } & E. coli $^{\boldsymbol{c}}$ & ${\text { S. } \text { aureus }^{\boldsymbol{d}}}$ & A. flavus & C. albicans \\
\hline 5 & 12 & 12 & 0.0 & 0.0 \\
8 & 12 & 12 & 18 & 0.0 \\
9 & 13 & 14 & 0.0 & 0.0 \\
10 & 13 & 15 & 0.0 & 0.0 \\
11 & 13 & 14 & 0.0 & 0.0 \\
13 & 13 & 13 & 0.0 & 0.0 \\
$14 \mathrm{a}$ & 12 & 12 & 0.0 & 0.0 \\
$14 \mathrm{~b}$ & 13 & 13 & 0.0 & 0.0 \\
$14 \mathrm{c}$ & 12 & 13 & 0.0 & 0.0 \\
15 & 14 & 15 & 0.0 & 0.0 \\
Standarde & 29 & 28 & $\mathrm{Nt}^{\mathrm{f}}$ & $\mathrm{Nt}^{\mathrm{f}}$ \\
Standardg & $\mathrm{Nt}^{\mathrm{f}}$ & $\mathrm{Nt}^{\mathrm{f}}$ & 18 & 20 \\
\hline
\end{tabular}

a DMSO has no antimicrobial activity at the concentration used to dissolve the test compounds

bIZD: inhibition zone diameter

c Gram- negative

d Gram- positive

e Standard for bacteria: Tetracycline

f Not tested

g Standard for fungi: Amphotericin B

\subsubsection{Materials}

Escherichia coli, Staphylococcus aureus, Aspergillus flavus and Candida albicans were used against the test compounds and were obtained from the Micro Analytical Center in Cairo University, Cairo, Egypt. Tetracycline and Amphotericin B were used as reference drugs and were also obtained from the same source.

\subsubsection{Method}

The antimicrobial profile was tested against Gram-negative, Gram-positive bacteria, mould and yeast using a modified Kirby-Bauer disc diffusion method [24,25]. The resulting inhibition zone diameters (IZDs) were measured in millimeters and used as criterion for the antimicrobial activity [24]. The size of the clear zone is proportional to the inhibitory action of the compound under investigation.

\subsubsection{Preparation of solutions of the compounds tested and reference drugs}

Standard discs of the bactericide Tetracycline and the fungicide Amphotericin B served as positive controls for antimicrobial activity but filter discs impregnated with $10 \mu \mathrm{l}$ of solvent (distilled water, chloroform, DMSO) were used as a negative control. Solvent controls showed no inhibition zones, confirming that they have no influence on growth of the tested microoganisms.

\subsubsection{Determination of minimum inhibitory concentration}

Determination of the minimum inhibitory concentration (MIC) of compound $\mathbf{1 5}$ against $S$. aureus was carried out using the agar dilution method, according to NCCLS guidelines [26] MIC value was given in $\mu \mathrm{g} / \mathrm{ml}$ and was compared to MIC value for the standard antibacterial drug Tetracycline. Screening result is summarized in Table 2. On the other hand, the MIC determination of compound $\mathbf{8}$ against $A$. flavus was achieved by the broth microdilution method [27]. Interestingly, the MIC of test compound $\mathbf{8}$ was found almost similar to MIC value for the standard antifungal drug Amphotericin B (Table 3).

Table 2. MIC of compound $\mathbf{1 5}$ and standard antibacterial drug against $S$. aureus.

\begin{tabular}{ll}
\hline \multirow{2}{*}{ Compd. } & MICa $(\boldsymbol{\mu g} / \mathbf{m L})$ \\
\cline { 2 - 2 } & S. aureus (Bacteria) \\
\hline 15 & 230 \\
Standardb & 82 \\
a MIC: Minimum Inhibitory Concentration
\end{tabular}

Table 3. MIC of compound $\mathbf{8}$ and standard antifungal drug against A. flavus.

\begin{tabular}{ll}
\hline \multirow{2}{*}{ Compd. } & MIC $(\boldsymbol{\mu} \mathrm{g} / \mathbf{m L})^{\text {A. } \text { flavus } \text { (Fungus) }}$ \\
\hline 8 & 168 \\
Standardb & 156 \\
\hline a MIC: Minimum Inhibitory Concentration
\end{tabular}

b Standard for fungi: Amphotericin B

\section{Results and discussion}

\subsection{Chemistry}

The diazo coupling reaction of the starting ethyl 2-amino-4phenylthiophene-3-carboxylate (1) [18-22] with diazotized aromatic and heterocyclic amines resulted in the formation of the corresponding 5-aryl- and 5-heteroarylazo derivatives 2a-d (Scheme 1). Hydrazinolysis of 4-methoxyphenylazo derivative 2b in ethanol provided the target aminocarbohydrazide $\mathbf{3}$, whose structure was confirmed by examining spectroscopic data and elemental analysis. Heterocyclization of carbohydrazide 3 with carbon disulfide in the presence of potassium hydroxide in ethanol led to one isolable product with molecular formula $\mathrm{C}_{19} \mathrm{H}_{15} \mathrm{~N}_{5} \mathrm{O}_{2} \mathrm{~S}_{2}$, which may be formulated as thieno[2,3d]pyrimidin-4-one $\mathbf{4}$ or 1,3,4-oxadiazole-2-thione $\mathbf{5}$. In the reaction of hydrazide $\mathbf{3}$ with thiourea in dimethylformamide we isolated a product whose analytical sample exhibited a different melting point from that obtained by the former route and their mixture showed a depression of the melting point although, according to elemental analysis data, both products had the composition $\mathrm{C}_{19} \mathrm{H}_{15} \mathrm{~N}_{5} \mathrm{O}_{2} \mathrm{~S}_{2}$. NMR spectroscopic analyses were not completely informative from the standpoint of choosing between the two isomeric structures $\mathbf{4}$ and $\mathbf{5}$, where the ${ }^{1} \mathrm{H}$ NMR spectra were similar in signal positions and intensities. The spectra contained resonances, which may be assigned to amino groups ( $\left.\delta_{H} 6.20-6.34 \mathrm{ppm}\right)$ and thioamidic protons $\left(\delta_{H} 12.58-13.65 \mathrm{ppm}\right)$, besides aromatic protons. Similarly, the ${ }^{13} \mathrm{C}$ NMR spectra indicated the presence of fifteen distinct carbon resonances in both compounds. However, IR spectra of both compounds were unambiguously able to discriminate between structures $\mathbf{4}$ and $\mathbf{5}$, by the observation of absorption bands belonging to stretching vibrations of $\mathrm{NH}, \mathrm{NH}_{2}$ and CS, which are characteristic for both structures, and a diagnostically important band at $v 1687 \mathrm{~cm}^{-1}$ arising from the carbonyl function, which is characteristic only for structure 4 but not for 5. On the basis of such data, it is not unreasonable to conclude that the studied reactions are completely 
regioselective and accordingly 1,3,4-oxadiazole $\mathbf{5}$ is isolated as the sole product by reaction of hydrazide $\mathbf{3}$ with carbon disulfide, whereas the alternative site of cyclization to the corresponding thienopyrimidinone 4 results from the reaction of compound $\mathbf{3}$ with thiourea. This observation is in complete agreement with previous literature reports on the wellestablished formation of 1,3,4-oxadiazoles by heating hydrazides with carbon disulfide in the presence of bases [2830].

In order to finally confirm the structure of compounds 4 and 5, they were subjected to a variety of chemical transformations as illustrated in Schemes 2 and 3 . Thienopyrimidin-4-one 4 reacted with phenyl isothiocyanate to produce the product of addition/cyclodesulfurization for which two isomeric structures $\mathbf{7}$ and $\mathbf{8}$ can be formulated. The signal of the $\mathrm{N}$-amino group, present in the ${ }^{1} \mathrm{H}$ NMR spectrum of 4 , was not detectable for the isolated product, demonstrating the disappearance of this group on ring closure. Elemental analysis data could not discriminate between the two isomeric structures $\mathbf{7}$ and $\mathbf{8}$. However, the structure of the isolated product was considered to be triazoline structure $\mathbf{8}$ rather than the alternative thiadiazole 7 as evidenced by spectroscopic studies. In the ${ }^{1} \mathrm{H}$ NMR spectrum of the reaction product, the signal associated with the $\mathrm{NH}$ proton was displayed at the typical downfield shift $\left(\delta_{H} 13.97 \mathrm{ppm}\right)$ as a singlet which disappeared upon addition of deuterium oxide. This downfield $\mathrm{NH}$ resonance in the isolated product from the studied reaction can be rationalized in terms of the presence of the thione group attached to the nitrogen atom linked to the thioamide proton and as a result this proton is deshielded by the thione group and appears around that chemical shift value. This assignment is in line with literature assignments, that predict this signal would appear typically in the range $\delta_{H} \sim 13.00-14.00 \mathrm{ppm}$ by analogy with related heterocyclic thioamides [31-37]. On the contrary, the isomeric structure 7 , if isolated, would be expected to display an upfield shift for the NH proton due to the absence of deshielding thione group. Conclusive evidence for the proposed structure 8 was provided by the ${ }^{13} \mathrm{C} N M R$ spectrum of the isolated product, where a diagnostic signal in the downfield region typically at $\delta_{C} 173.2$ ppm was detected. Such a downfield signal can be assigned only to the thioamide CS carbon atom, which was reported to appear at $\delta_{C}$ value greater than $169 \mathrm{ppm}$ in related systems [37-40]. It is worthwhile to report here that the thione form is the stable form in which compound $\mathbf{8}$ mainly exists since its IR spectrum revealed no absorption band at around $v 2600-2550 \mathrm{~cm}^{-1}$, which is indicative of the thiol form [35,36,41-43]. In the ${ }^{1} \mathrm{H}$ NMR spectrum of $\mathbf{8}$, the absence of a signal due to the $\mathrm{SH}$ proton that would be expected to resonate in the range $\delta_{H} 1.6-$ $4.0 \mathrm{ppm}[35,37]$ also provided confirmatory evidence for thione formation. The prevalence of the thione rather than the thiol form in a number of heterocyclic systems is well-established [44-46]. The preferred formation of the triazoline ring under alkaline conditions may be due to the enhanced nucleophilicity of the nitrogen atom attached to phenyl group of the Nphenylthiourea moiety in the acyclic adduct $\mathbf{6}$ in reaction with the thione carbon, particularly on deprotonation, followed by cyclodesulfurization [47]. As a result, triazoline-2-thione derivative $\mathbf{8}$ was isolated as the sole product (Scheme 2).

This protocol was also suitable for the synthesis of tricyclic thiadiazines, where alkylation of thienopyrimidin-4-one 4 with phenacyl bromide in alkaline medium led to the thiadiazine derivative 9, whereas with chloroacetic acid in the presence of sodium acetate the product was identified as thiadiazinone derivative 10. Moreover, compound $\mathbf{1 0}$ could be also obtained by an alternative method utilizing the reaction of pyrimidinone derivative 4 with ethyl chloroacetate in ethanolic sodium ethoxide solution. The latter products $\mathbf{9}$ and $\mathbf{1 0}$ are assumed to be formed via initial S-alkylation of amino-thioxo derivative $\mathbf{4}$, followed by cyclocondensation in a fashion similar to established $\alpha$-aminothione derivatizations [48-50]. By reaction of compound $\mathbf{4}$ with benzoic acid in the presence of phosphorus oxychloride we obtained the thiadiazole derivative 11 via dehydrative cyclization, in accordance with the findings of related reports [50-53]. Nevertheless, the outcome of reactions of compound $\mathbf{4}$ with various electrophilic reagents, as shown in Scheme 2, can be regarded as a rigorous proof for constitution of thienopyrimidin-4-one $\mathbf{4}$, locating the amino and thioxo groups in positions 3 and 2 , respectively.

On the other hand, 1,3,4-oxadiazole-2-thione 5 was also submitted to a series of transformations that served as an additional means of confirmation of compound identity (Scheme 3). Thus, treating compound $\mathbf{5}$ with hydrazine hydrate produced only one isolable product (by TLC analysis) that was identified as 4-aminotriazolethione derivative $\mathbf{1 3}$, according to its elemental analysis and spectral data besides chemical proof, and not the other possible 5-hydrazino-1,3,4-oxadiazole product 14c. Mass spectrometry provided a powerful tool for distinguishing between the possible structures 13 and 14c as it was shown, in the mass spectrum of the isolated product, a molecular ion peak at $m / z$ 423. This peak is compatable with the molecular formula of $\mathbf{1 3}$ but not 14c. In the ${ }^{1} \mathrm{H}$ NMR spectrum of the same product, the presence of three $\mathrm{D}_{2} \mathrm{O}$ exchangeable singlet signals, one of them detected at the typical lowfield shift ( $\delta_{H} 13.24 \mathrm{ppm}$ ) characteristic for the highly deshielded thioamidic hydrogen, was also confirmatory evidence in favor of structure 13. Other resonances were observed as expected and are recorded in the experimental section. Thus, the analytical and spectroscopic data led us to presume that the obtained product from the heteroannelation reaction was not the 5-hydrazino-1,3,4-oxadiazole derivative 14c and instead the 4-aminotriazole-5-thione derivative 13 was isolated. The pathway of the studied reaction may involve initial nucleophilic attack by the amino group of hydrazine hydrate on the thione carbon atom with subsequent cleavage of the $\mathrm{C}-\mathrm{O}$ bond and as a result the oxadiazole ring opening results in the intermediate formation of acyclic adduct $\mathbf{1 2}$. Subsequent recyclization could then take place via nucleophilic attack by the carbothiohydrazide NH moiety on the amidic carbonyl group. This would be accompanied by cyclodehydration, leading eventually to the aminotriazoline derivative 13. This hypothesis is consistent with our earlier report [54] and with other similar observations [55-57].

In support of this hypothesis, the discrimination between structures 13 and 14c was further proved chemically via the synthesis of compound $\mathbf{1 4 c}$ by an unambiguous method involving initial alkylation of $\mathbf{5}$ with methyl iodide and subsequent treatment of the formed methylthio derivative 14a with hydrazine hydrate, yielding the respective hydrazino derivative 14c. Compound 14c prepared by this sequence of reactions proved to be different from the previously isolated sample 13 as indicated by TLC analysis, m.p., mixed m.p. and IR data of the reaction product in each case. In the ${ }^{1} \mathrm{H}$ NMR spectrum of hydrazino compound 14c, the resonance of the $\mathrm{NH}$ proton was shifted upfield to $10.35 \mathrm{ppm}$, indicating the disappearance of the deshielding thione group. The remaining resonances were also observed at the expected frequencies (see Experimental section). The constitution of $\mathrm{N}$-amino compound 13 was well supported as it afforded the corresponding triazolothiadiazine derivative $\mathbf{1 5}$ on alkylation with phenacyl bromide (Scheme 3).

By using the synthetic sequence as was suggested for the synthesis of hydrazino derivative 14c, interestingly, product 15 was again formed via initial alkylation of compound $\mathbf{5}$ with phenacyl bromide in alkaline medium to provide the corresponding phenacylthio derivative 14b. Following this step, the alkylated product $\mathbf{1 4 b}$ was treated with hydrazine hydrate. The final product of this synthetic sequence was identified as triazolothiadiazine derivative $\mathbf{1 5}$ according to TLC analysis, m.p., mixed m.p. and IR data of the isolated material. The formation of compound $\mathbf{1 5}$ in this case could proceed via initial oxadiazole ring opening with subsequent 
heterocondensation and spontaneous cyclodehydration. This fact gives added proof for the structure of the previously obtained sample $\mathbf{1 5}$ by the former route.

In contrast to the reactivity of thienopyrimidin-4-one 4 towards phenyl isothiocyanate, oxadiazole-2-thione $\mathbf{5}$ failed to react with phenyl isothiocyanate, using different solvents and catalysts, in an attempt to prepare $\mathrm{N}$-phenylthiourea derivative 16. This result may be because of steric hindrance created by the ortho orientated oxadiazole ring or the reduced nucleophilicity of the (oxadiazolyl)thiophenylamine. On the other hand, the acetylation of methylthio derivative 14a with acetic anhydride readily occurred to give the corresponding 2acetylamino derivative $\mathbf{1 7}$ (Scheme 3). Elucidation of structure for the latter product was established on the basis of elemental and spectroscopic analyses (see Experimental section).

\subsection{Antimicrobial evaluation}

The biological evaluation of antibacterial and antifungal effects are summarized in Table 1. As shown by these results, the new thiophene-based derivatives under investigation displayed variable in vitro antibacterial and antifungal actions. In general, the chemical structure, comprising the nature of the heterocyclic system as well as the substituted function present in the heterocyclic ring, has a pronounced effect on antimicrobial activity. In particular, it has been found that antimicrobial activity was relatively dependent on the substituent at the 3-position of thiophene ring. It was observed that compounds substituted with a triazolothiadiazine moiety at the 3-position of the heterocyclic nucleus showed promising antibacterial activity especially against the Gram-positive strain. On the contrary, there was no essential in vitro antifungal profile of the compounds under investigation against test fungi isolates except for condensed thiophene derivative $\mathbf{8}$, which was found to be as effective as Amphotericin B with the same inhibition zone diameter (IZD) value against Aspergillus flavus (Table 1). Based on the antimicrobial evaluation, compounds $\mathbf{8}$ and $\mathbf{1 5}$ were selected for further assessment.

The minimum inhibitory concentration (MIC) of uncondensed thiophene derivative $\mathbf{1 5}$ against $S$. aureus was $230 \mu \mathrm{g} / \mathrm{mL}$, which is higher than that of Tetracycline as a reference antibacterial drug as depicted in Table 2. In contrast, the MIC of condensed thiophene derivative 8 against $A$. flavus was $168 \mu \mathrm{g} / \mathrm{mL}$, which is very close to that of Amphotericin B as a reference antifungal drug (Table 3). From the structureactivity relationship (SAR), we can conclude that the triazolothiadiazine moiety is essential for antibacterial activity especially against the Gram-positive strain. In addition, heteroannelation of thienopyrimidinone to a triazole-thione moiety can improve antifungal activity as observed for compound 8, which can be considered as a lead compound in this field. Further studies are in progress on both compounds to increase their efficacy and understand their QSAR.

The overall results of the present study can be considered promising in the perspective of new antifungal drug discovery, considering the clinical importance of the tested microorganisms. Of particular interest, $S$. aureus may occur as a commensal on skin; it also occurs in the nose frequently (in about a third of the population) [58] and throat less commonly. The occurrence of $S$. aureus under these circumstances does not always indicate infection and therefore does not always require treatment. In infants, $S$. aureus infection can cause a severe disease staphylococcal scalded skin syndrome (SSSS) [59]. This pathogen was found to be sensitive to most of the test compounds especially compounds $\mathbf{1 0}$ and $\mathbf{1 5}$ (Table 1). Aspergillus causes chronic necrotizing pulmonary aspergillosis (CNPA) [60], which is a subacute infection seen in patients with an underlying lung disease. About $50 \%$ of reported cases have shown no response to amphotericin B [61]. The most common subtype among paranasal sinus infections associated with aspergillosis is Aspergillus fumigatus [62]. The symptoms include fever, cough, chest pain or breathlessness, which also occur in many other illnesses so diagnosis can be difficult. Such a pathogen was found to be highly sensitive to compound 8 (Table 1). Candida albicans has been identified as the major opportunistic pathogen in the etiology of fungal infections [63]. Candidiasis is an increasingly important desease, which is distributed worldwide because of this opportunistic pathogen and other candida species. Candidiasis is often observed in immunocompromised individuals such as HIV-positive and AIDS patients [61]. Unfortunately, this fungus was not found to be sensitive to any of the synthesized compounds (Table 1).

\section{Conclusion}

In conclusion, we have unambiguously proved in the present study by spectroscopic methods and chemical transformations that reaction of carbohydrazide 3 with carbon disulfide in alkaline medium yields the 1,3,4-oxadiazole-2thione derivative $\mathbf{5}$, while the alternative thienopyrimidin-4one structure $\mathbf{4}$ is the product of the reaction of hydrazide $\mathbf{3}$ with thiourea. Heterocyclization of compounds $\mathbf{4}$ and $\mathbf{5}$ provided an easy and versatile access to a variety of condensed and uncondensed thiophenes of potential biological interest. The biological potential of the new thiophene-based derivatives was further investigated by screening their antimicrobial activity against two pathogenic bacteria and two pathogenic fungi. Biological study of the compounds under investigation indicated that the most prominent and consistent antibacterial activity was obtained with compound $\mathbf{1 5}$ carrying a triazolothiadiazine moiety attached to the thiophene ring at the 3-position. Compound $\mathbf{8}$ showed an appreciable antifungal action against $A$. flavus similar to that of the reference drug. Its MIC value towards $A$. flavus is very significant. In light of the results presented in this work and taking into account that this preliminary study does not produce conclusive evidence regarding structure-antimicrobial relationships, we have focused our attention on the most promising compounds $\mathbf{8}$ and 15 as an interesting starting point for the development of a new class of antimicrobial agents. Further structural modifications of these type of molecules might lead to the discovery of more potent antimicrobial agents and this work is in progress. We believe that research in this direction should be encouraged in order to broaden the applicability of these new heterocyclic frameworks to serve as leads for designing novel chemotherapeutic agents.

\section{Acknowledgements}

One of the authors (H. M. Gaber) would like to express his sincere gratitude to the School of Chemistry, Cardiff University, U.K., for granting him a research fellowship and for all facilities provided to this fellowship. Financial support from Cardiff University, the Engineering and Physical Sciences Research Council (EPSRC) and the Biotechnology and Biological Sciences Research Council (BBSRC), in collaboration with the University of Wales College of Medicine, UK, is gratefully acknowledged.

\section{References}

[1]. Weinberg, E. D. Antifungal agents. In Burger's Medicinal Chemisrty and Drug Discovery, fifth ed., Wiley-Interscience: New York, 1996; Vol. 2, pp. 637-652.

[2]. Petrov, O.; Gerova, M.; Petrova, K.; Ivanova, Y. J. Heterocyclic Chem. 2009, 46, 44-48.

[3]. Wildfeuer, A.; Seidl, H. P.; Paule, I.; Haberreiter, A. Mycoses 1998, 41, 309-319.

[4]. Daidone, G.; Maggio, B.; Schillaci, D. Pharmazie 1990, 45, 441-442. 
[5]. Franchini, C.; Muraglia, M.; Corbo, F.; Florio, M. A.; Mola, A. D.; Rosato, A.; Matucci, R.; Nesi, M.; Bambeke, F. V.; Vitali, C. Arch. Pharm. Chem. Life Sci. 2009, 342, 605-613.

[6]. Pinto, E.; Queiroz, M.-J. R. P.; Vale-Silva, L. A.; Oliveira, J. F.; Begouin, A.; Begouin, J.-M.; Kirsch, G. Bioorg. Med. Chem. 2008, 16, 8172-8177.

[7]. Daniel, V. P.; Murukan, B.; Kumari, B. S.; Mohanan, K. Spectrochim. Acta A 2008, 70A, 403-410.

[8]. Ghorab, M. M.; Amin, N. E.; El Gaby, M. S. A.; Taha, N. M. H.; Shehab, M. A.; Faker, I. M. I. Phosphorus, Sulfur Silicon Relat. Elem. 2008, 183, 2918-2928.

[9]. Darwish, E. S. Molecules 2008, 13, 1066-1078.

[10]. Queiroz, M. J. R. P.; Ferreira, I. C. F. R.; De Gaetano, Y.; Kirsch, G.; Calhelha, R. C.; Estevinho, L. M. Bioorg. Med. Chem. 2006, 14, 68276831.

[11]. Carrillo-Munoz, A. J.; Giusiano, G.; Ezkurra, P. A.; Quindos, G. Expert Rev. Anti-Infect. Ther. 2005, 3, 333-342.

[12]. Chambhare, R. V.; Khadse, B. G.; Bobde, A. S.; Bahekar, R. H. Eur. J. Med. Chem. 2003, 38, 89-100.

[13]. El-Sharief, A. M. Sh.; Micky, J. A. A.; Shmeiss, N. A. M. M.; El-Gharieb, G. Phosphorus, Sulfur Silicon Relat. Elem. 2003, 178, 439-451.

[14]. El-Sherbeny, M. A.; El-Ashmawy, M. B.; El-Subbagh, H. I.; El-Emam, A. A.; Badria, F. A. Eur. J. Med. Chem. 1995, 30, 445-449.

[15]. Gaber, H. M.; Bagley, M. C. ChemMedChem 2009, 4, 1043-1050.

[16]. Filichev, V. V.; Gaber, H.; Olsen, T. R.; Jørgensen, P. T.; Jessen, C. H.; Pedersen, E. B. Eur. J. Org. Chem. 2006, 17, 3960-3968.

[17]. Gaber, H. M.; Elgemeie, G. E. H.; Ouf, S. A.; Sherif, S. M. Heteroat. Chem. 2005, 16, 298-307.

[18]. Gewald, K.; Schinke, E.; Boettcher, H. Chem. Ber. 1966, 99, 94-100.

[19]. Perrissin, M.; Duc, C. L.; Narcisse, G.; Bakri-Logeais, F.; Huguet, F. Eur. J. Med. Chem. 1980, 15, 563-565.

[20]. Hallas, G.; Choi, J.-H. Dyes Pigments 1999, 40, 99-117.

[21]. Koebel, R. F.; Needham, L. L.; Blanton, Jr., C. D. J. Med. Chem. 1975, 18, 192-194.

[22]. Tormyshev, V. M.; Trukhin, D. V.; Rogozhnikova, O. Y.; Mikhalina, T. V.; Troitskaya, T. I.; Flinn, A. Synlett 2006, 16, 2559-2564.

[23]. Gewald, K.; Gruner, M.; Hain, U.; Sueptitz, G. Monatsh. Chem. 1988, 119, 985-992.

[24]. Bauer, A. W.; Kirby, W. W. M.; Sherris, J. C.; Turck, M. Am. J. Clin. Pathol 1966, 45, 493-496.

[25]. Pfaller, M. A.; Burmeister, L.; BartlettGhorab, M. A.; Rinaldi, M. G. J. Clin Microbiol. 1988, 26, 1437-1441.

[26]. National Committee for Clinical Laboratory Standards, Method for Dilution Antimicrobial Susceptibility Tests for Bacteria that Grow Aerobically; Approved Standard, fourth ed. NCCLS Document M7-A4 Wayne, PA, USA, 1997.

[27]. Wu, L.; Pan, J.; Thoroddsen, V.; Wysong, D. R.; Blackman, R. K.; Bulawa C. E.; Gould, A. E.; Ocain, T. D.; Dick, L. R.; Errada, P.; Dorr, P. K.; Parkison, T.; Wood, T.; Kornitzer, D.; Weussman, Z.; Willis, I. M. Eukaeyotic Cell 2003, 2, 256-264.

[28]. Ainsworth, C. J. Am. Chem. Soc. 1956, 78, 4475-4478.

[29]. Aboraia, A. S.; Abdel-Rahman, H. M.; Mahfouz, N. M.; El-Gendy, M. A. Bioorg. Med. Chem. 2006, 14, 1236-1246.

[30]. Abdel-Rahman, H. M.; Hussein, M. A. Arch. Pharm. Chem. Life Sci. 2006, 339, 378-387.

[31]. Küçükgüzel, İ.; Küçükgüzel, Ș. G.; Rollas, S.; Ötük-Saniș, G.; Özdemir, O.; Bayrak, İ.; Altuğ, T.; Stables, J. P. Farmaco 2004, 59, 893-901.

[32]. Oruç, E. E.; Koçyigit-Kaymakçioglu, B.; Oral, B.; Altunbas-Toklu, H. Z.; Kabasakal, L.; Rollas, S. Arch. Pharm. Chem. Life Sci. 2006, 339, $267-$ 272.

[33]. Güzeldemirci, N. U.; Küçükbasmaci, Ö. Eur. J. Med. Chem. 2010, 45, 6368.

[34]. Küçükgüzel, İ.; Küçükgüzel, Ș. G.; Rollas, S.; Kiraz, M. Bioorg. Med. Chem. Lett. 2001, 11, 1703-1707.

[35]. Gürsoy, A.; Demirayak, Ș.; Cesur, Z.; Reisch, J.; Ötük, G. Pharmazie 1990, 45, 246-250.

[36]. Rollas, S.; Kalyoncuoğlu, N.; Sur-Altiner, D.; Yeğenoğlu, Y. Pharmazie 1993, 48, 308-309.

[37]. Cho, N. S.; Kim, G. N.; Parkanyi, C. J. Heterocyclic Chem. 1993, 30, $397-$ 401.

[38]. Elmoghayar, M. R. H.; Ghali, E. A.; Ramiz, M. M. M.; Elnagdi, M. H. Liebigs Ann. Chem. 1985, 10, 1962-1968.

[39]. Bartels-Keith, J. R.; Burgess, M. T.; Stevenson, J. M. J. Org. Chem. 1977, 42, 3725-3731.

[40]. Pappalardo, S.; Bottino, F.; Tringali, C. J. Org. Chem. 1987, 52, 405-412.

[41]. Ram, V. J.; Mishra, L.; Pandey, N. H.; Kushwaha, D. S. J. Heterocyclic Chem. 1990, 27, 351-355.

[42]. Ergenc, N.; Ilhan, E.; Ötük, G. Pharmazie 1992, 47, 59-60.

[43]. Shaker, R. M.; Mahmoud, A. F.; Abdel-Latif, F. F. Phosphorus, Sulfur Silicon Relat. Elem. 2005, 180, 397-406.

[44]. Sandström, J.; Wennerbeck, I. Acta Chem. Scand. 1966, 20, 57-71.

[45]. Still, I. W. J.; Plavac, N.; McKinnon, D. M.; Chauhan, M. S. Can. J. Chem. 1976, 54, 280-289.

[46]. Still, I. W. J.; Plavac, N.; McKinnon, D. M.; Chauhan, M. S. Can. J. Chem. 1976, 54, 1660-1664.

[47]. El-Essawy, F. A.; Khattab, A. F.; Abdel-Rahman, A. A. H. Monatsh. Chem. 2007, 138, 777-785
[48]. Nawrocka, W.; Zimecki, M. Arch. Pharm. Pharm. Med. Chem. 1997, 330, 399-405.

[49]. Britsun, V. N.; Esipenko, A. N.; Kudryavtsev, A. A.; Lozinskii, M. O. Russ. J. Org. Chem. 2005, 41, 1333-1336.

[50]. Gogol, P. C.; Kataky, J. C. S. Heterocycles 1990, 31, 2147-2152.

[51]. Ilango, K.; Valentina, P. Eur. J. Chem. 2010, 1, 50-53.

[52]. Golgolab, H.; Lalezari, I.; Hosseini-Gohari, L. J. Heterocyclic Chem. 1973, 10, 387-390.

[53]. Ibrahim, D. A. Eur. J. Med. Chem. 2009, 44, 2776-2781.

[54]. Anwar, H. F.; Metwally, N. H.; Gaber, H.; Elnagdi, M. H. J. Chem. Research 2005, 1, 29-31.

[55]. Vainilavicius, P.; Smicius, R.; Jakubkiene, V.; Tumkevicius, S. Monatsh. Chem. 2001, 132, 825-831.

[56]. Elkholy, Y. M.; Ali, K. A.; Farag, A. M. J. Heterocyclic Chem. 2006, 43, 1183-1188.

[57]. Almasirad, A.; Vousooghi, N.; Tabatabai, S. A.; Kebriaeezadeh, A Shafiee, A. Acta Chim. Slov. 2007, 54, 317-324.

[58]. Salyers, A. A.; Whitt, D. D. Bacterial Pathogenesis: A Molecular Approach; second ed., ASM Press: Washington, D. C., USA, 2002, pp. 539. ISBN 1-55581-171-X.

[59]. Curran, J. P.; Al-Salihi, F. L. Pediatrics 1980, 66, 285-290.

[60]. Saraceno, J. L.; Phelps, D. T.; Ferro, T. J.; Futerfas, R.; Schwartz, D. B. Chest 1997, 112, 541-548.

[61]. Cowan, M. M. Clin. Microbiol. Rev. 1999, 12, 564-582.

[62]. Bozkurt, M. K.; Ozçelik, T.; Saydam, L.; Kutluay, L. Kulak Burun Bogaz Ihtis. Derg. 2008, 18, 53-55.

[63]. Di Santo, R.; Tafi, A.; Costi, R.; Botta, M.; Artico, M.; Corelli, F.; Forte, M.; Caporuscio, F.; Angiolella, L.; Palamara, A. T. J. Med. Chem. 2005, 48, 5140-5153. 